\title{
Space and Networks: Mexico City and \#Yosoy132
}

\section{Alan Grabinsky Zabludovsky, New York University, USA}

\begin{abstract}
:
The first Internet-driven political movement in Mexican history started two years ago in Mexico City. The movement, called \#yosoy132, was integrated by university students denouncing the alleged support of media giant Televisa to presidential candidate Enrique Peña Nieto. Mexico City became a platform for the movement, allowing multiple actors to participate across space and time.
\end{abstract}

During the protest, public space became a hybrid realm in which global and local networks coincided. The Internet reconfigured the relation of urbanites to space and to each other, and face-to-face encounters, mediated by social networks, allowed for protestors to cohere in a collective identity. This was an ephemeral moment, however, that latter succumbed to the fragmented life of the megalopolis.

In the paper I will show how the events that lead to the massive protest of \#yosoy132 in the city center did not take place in a vacuum; they developed in particular areas of the city that are intersected by different local and global threads. Spaces in cities are connected to each other in different ways, the Internet is one: participation in it extends the field of action of a crowd or an individual beyond the limits set up by the built environment. Thus, a crowd that congregates in a secluded space and tweets about it is creating a sense of events unfolding precisely throughout the whole city because of their networked visibility. 


\section{\#YOSOY132:}

In May 11th, 2011, the presidential candidate for the Coalition for Mexico, Enrique Peña Nieto, visited the campus of the Iberoamericana University as part of his electoral campaign. He was the candidate of the PRI (PartidoRevolucionarioInstitucional), a party that had ruled Mexico for 72 year-until, in 2000, the first opposition party to win an election in Mexico, the PAN (PartidoAcciónNacional), came to power. The PRI lost to the PAN because during that time, it was considered representative of a technocratic and censoring regime and associated with corruption and autarchic power.

Peña Nieto, however, was in a different public standing with regards to public opinion. He was well ahead of other candidates in the polls and most Mexicans saw him as a promising new face to the old party. His popularity however, was, according to his critics, tied to the fact that Televisa, one of the world's largest media conglomerates, was secretly backing him up.

During the PRI governance, Televisa was the government's voice to the people. The 1968 student massacre in Mexico City for example, never happened, according to the main news program of that time. Like the PRI, by the end of the twentieth century it was increasingly seen as a corrupt and manipulative medium that constantly lied to the people. (Villamil, 2012)

Even though Televisa depended on the PRI to exist, the PRI's failure in the elections did not affect Televisa. In fact, Televisa's power grew exponentially. From the 1990's until now, Televisa has become one of the most important multinational conglomerates in the world, with influence beyond the Latin American region and with central offices in Miami, Los Angeles and New York. According to Mexican reporter JenaroVillamil, the media conglomerate has so much power that it influences the Mexican governments' capacity for self-determination.

In the midst of this growth of Televisa's overarching shadow, Enrique Peña Nieto, started appearing, years before the election, in many of Televisas' media outlets (magazines, shows, etc). His image was that of a prince charming, a handsome "galan de telenovela" (soap opera stud). Many critics saw, in this shallow image of the knight in shining armor, the work of Televisa's marketing team. EPN's image was designed, according to them, to cater to the dreams of the fantasies of the Mexican uneducated public. 
That day in the Universidad Iberoamericana, Enrique Peña Nieta was confronted with an angry crowd that called him a puppet for Televisa. Peña Nieto was not expecting this type of attitude from the students; private universities, like Universidad Iberoamericana, are generally more complacent with the status quo and less prone to massive rallies than public universities. The scenes of unrest were such a surprise to the students themselves that many of them recorded them through their smart-phones. The videos were immediately posted up on social networks like YouTube, creating an instant buzz that extended beyond the campus grounds.

The next day Televisa acted in a way that was reminiscent of the old role it had with PRI regime. It reported that only a handful of people had protested against the candidate and that they were illegitimate rabble-rousers that had nothing to do with the university. As a response to this belittling statement, the 131 students that participated in the protest organized a video showing their University ID and reiterating their stance vis-à-vis the candidate. This video went viral, and by the end of the 12 of May the \#yosoy132 hashtag became a trending topic throughout the twitter platform. The hashtag was as a form of support, implying that the user is the "132nd" protestor. The initial "trigger", the dramatic event that unfolded in the Universidad Iberoamericana was later followed by an avalanche of events that instantly conjured images of other networked social movements--like the ones that developed in Cairo and New York.

Two days after the original event, students organized a march from the university towards the nearby headquarters of Televisa. The march was recorded and tweeted live, and anyone with Internet access could see the images and videos of the students approaching the Televisa building. This experience of watching the action happen in real time allowed onlookers to feel part of an imagined community of protestors. The network, created by the Internet and specifically through social media, linked different parts of the city with each other, regardless of the distance in space. The images even jumped into the Mexican Diaspora where it inspired movements of protest amongst university students worldwide. Nationally, the symbolism of protest created an avalanche of anti-Peña Nieto feelings, particularly amongst university students. In 19th of March there was a spontaneous and massive rally of thousands of people in Reforma, one of the main streets of Mexico City and heading towards the main public space of the city, the Zocalo. 
According to Elias Canneti, crowds have open and closed nature. Open crowds are crowds that are continually growing and are highly volatile and dynamic. Closed crowds have more of a ritualistic essence; they meet in one place or another at regular intervals. Crowds also have speeds--the quick crowd forms towards an attainable goal that is near (like killing someone) the slow crowd moves towards a larger goal (changes in land zoning, for example). The \#yosoy132 movement started as an open, quick crowd that fed on an emotion, anger against Televisa and Peña Nieto. After the initial massive protest, however, the crowd had to turned into a closed crowd and got fragmented as the goal shifted from immediate anger to the long-term goal of stopping Enrique Peña Nieto from reaching the presidency.

Teasing out the intersection of networks and cities can be problematic: in many cases, the spatial dimensions of cities are lost because of the focus on larger and more virtual conception of a network. In this sense, geographer Jennifer Robinson argues that the focus on territory is essential to think about the city in relation to other networks: 'By paying attention to the city-as a territory, as a platform, or in relation to citywide processes--the diversity of city life and the multiplicity of networks and connection which spat it can come into view" (Robinson, 763). This is done by developing a spatial imagination that is multiple and sophisticated, focusing on "networks and clusters; boundaries and globalizing forces: communities of responsibility as well as social fragmentation”. (Robinson, 763)

Given this special dimension of networks we can state that the events that lead to the massive protest of \#yosoy132 in the city center did not take place in a vacuum, they developed in particular areas of the city that are intersected by different local and global threads. Spaces in cities are connected to each other in different ways. The Internet is one of way, as participation in it extends the field of action of a crowd or an individual beyond the limits set up by the built environment. Thus, a crowd that congregates in a secluded space and tweets about it is creating a sense of events unfolding precisely throughout the whole city because of their networked visibility.

Vicente Gallo and Garcia Canclini both talk about Santa Fe, where the protest took place, as an area that manifests all the contradictions of a globalized urbanism. Like one of the many generic cities being developed in places like Abu Dhabi and Singapore, it is also one of the most connected areas of the city-- with high-rise buildings hosting multinational corporations 
and 6-laned highways connecting cars to important areas of the city. In Santa Fe there are no public spaces--other than malls. It can be considered as a place where social heterogeneity is sacrificed for economic efficiency. It is far away from the city center, and is only accessible by car.

In other words, Santa Fe is not the typical place to make a protest--this is what made the events around the 11th and 12th of May stand out so much. The fact that protestors were marching down a space designed entirely for transit, far away from the city center and towards a media conglomerate was an eerie sight which made their actions appear more dramatic. Luckily, Televisa headquarters are only a couple of blocks away from the Universidad Iberoamericana, as shown in the map below.

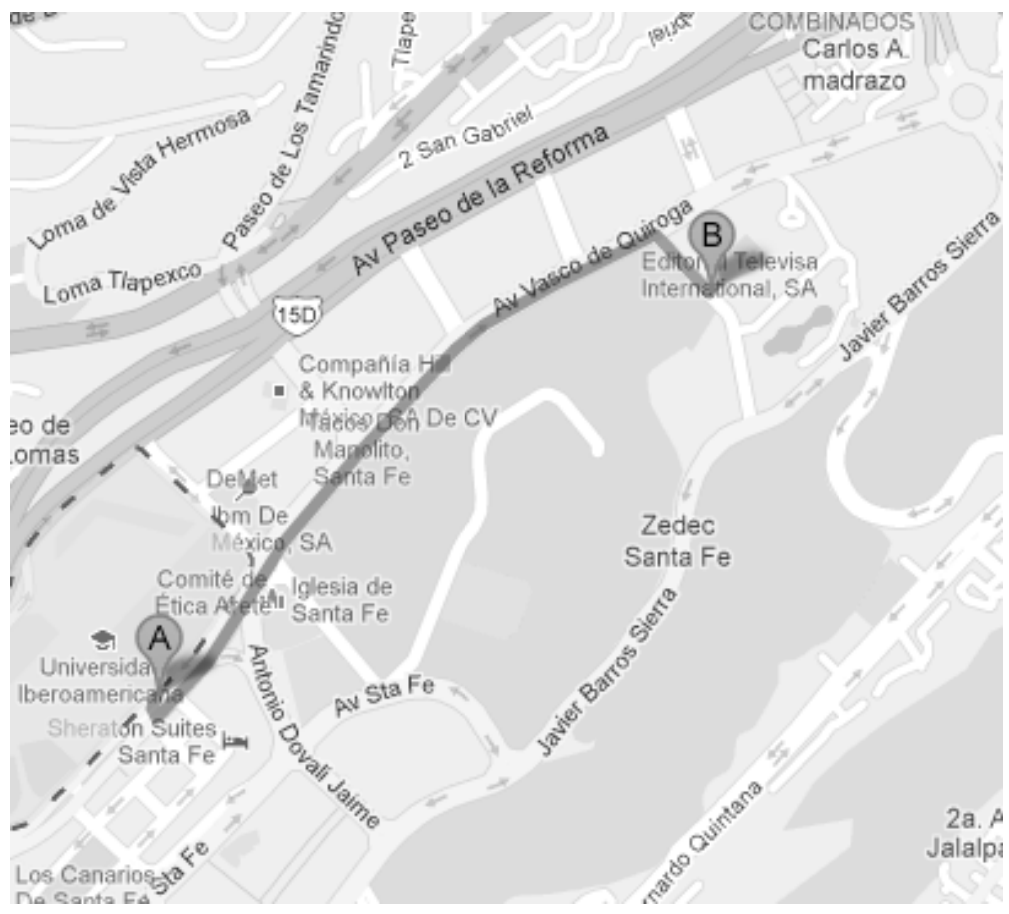

Figure 1: Walking route from Universidad Iberoamericana to Televisa Santa Fe (Google Maps)

This physical proximity of one institution to another was serendipitous because of the importance of Televisa to Mexico City’s daily life. In an expansive megalopolis like Mexico City media plays the role of unification and articulation of lived experiences. According to Nestor Canclini, the city-dweller’s experience of Mexico City has passed from the long-form 
narratives of the lettered city to the instant flashes of information. For the city dweller, the interest in the total city is abandoned for multiple and unstable forms of communal interaction. Thus, city dwellers organize their experience of space selectively and through mass media-like TV and radio—-which then become the articulators of this dispersed city and the organizer of the public space. Concise bursts of information through Twitter and Facebook also articulate the activities of the city, creating a sense of an active community in real time.

Networked spaces are not only networked locally but globally. In her seminal book, "The Global City”, Saskia Sassen states that cities are becoming increasingly important as central nodes for the organization of the global economy. Special areas of Cairo, New York, Madrid, Mexico City and other cities perform as command centers in transnational circuits of exchange. Sassen's study focuses on the areas where the upper management of transnational companies and finance industries concentrate, but many authors have argued that the global aspect of a city can be approached using other variables, like media industries (which, according to Manuel Castells are also linked to financial networks).

Similarly, Gallo thinks we must think comparatively about megalopolises in order to understand deeper human trends. "In the twenty-first century, Mexico City has undoubtedly more in common (in terms of urban cultures, social problems and planning issues) with other developing cities around the worlds--from Buenos Aires to Karachi-than with the bygone City of Palaces extolled by Humboldt” (Gallo, 9). One of the spaces that is comparable to other cities is Santa Fe, a global space of hyper connectivity where one can find an administrative center of media monopolies and the regional headquarters of important bank in a two blocks ratio

Established networks, like the ones maintained by media conglomerates, are programmed to interact with other networks of power, like governments and other institutions, in ways that maintain the status quo. Movements based on social media and the Internet are able to reprogram these existing networks of power or disrupt them precisely because they take place in the periphery of the institutions (Castells, 2012). In this sense, the network established by the Internet challenged the authority of narratives developed by established media conglomerates like Televisa. 
The actual public space of Santa Fe, then, became the periphery of the transnational institutions of the area that are lodged there. The street outside Televisawas not meant as a pedestrian space, in this sense, occupying it meant circumventing the power of Televisa as an institution designed for global transmission of media content. In other words, Televisa could curate what appeared on the screens of many households across Mexico and Latin America, but it could not control what appeared outside the Santa Fe building doors.

A graphic representation of social media allows us to understand the connection between globalization, urbanization and social media usage. Eric Fischer has produced stunning maps locating geo-tagged photos of Twitter and Flickr in the world. These maps are interesting because they frame an activity that, because of its communicative nature, points beyond itself. The map could be considered as a representation of instances of relational space, putting actors in relation to each other via networks (Mcquire, 2008). Although we cannot grasp the nature of these multiple networks through these maps, we can understand them as happening simultaneously and in a geographic space.

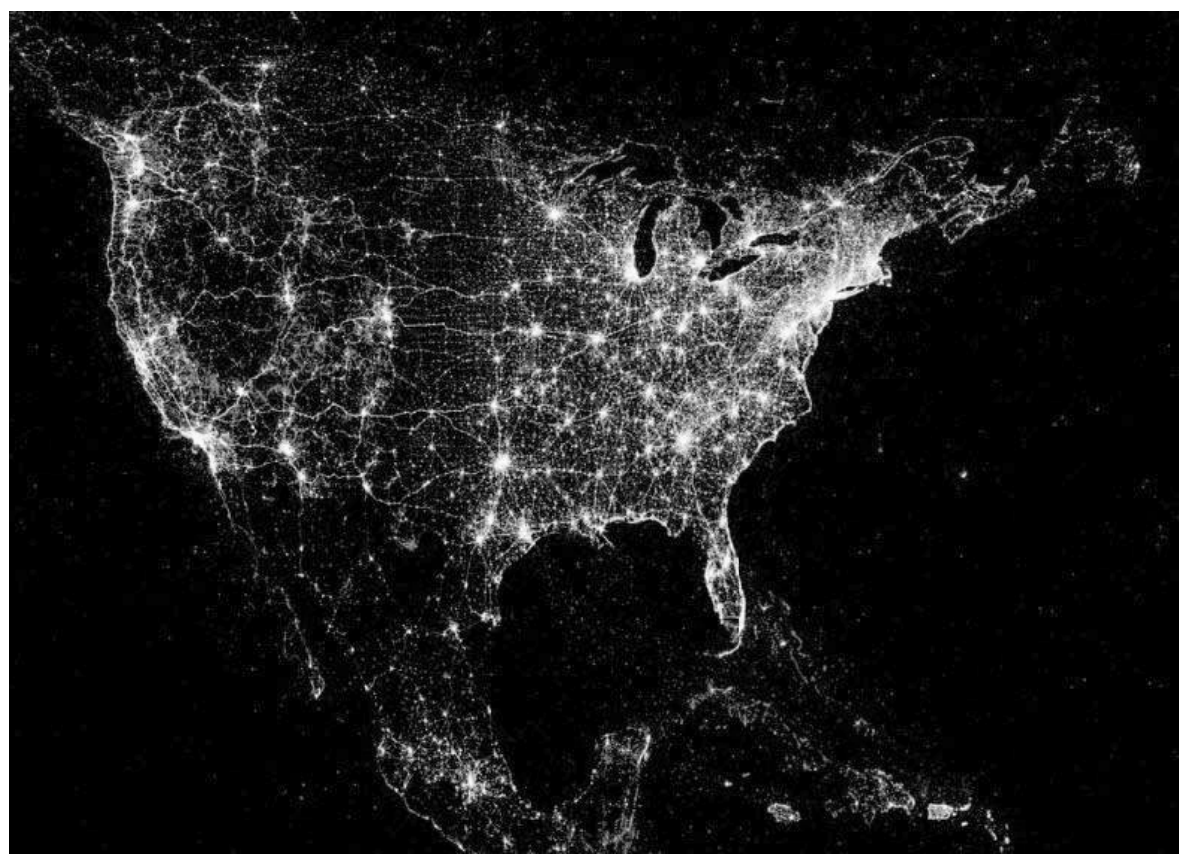

Figure 2: Map of geotagged tweets shows urban regions as nodes in media circuits (Eric Fisher, Flickr) 
The picture above show that, the highest twitter usage happens in highly dense metropolitan areas. If we zoom in to Mexico City, we can take this correlation of social media and density even further to include public squares and pedestrian streets. Spaces of high density are not only the ultimate zones for connecting face to face, but also virtually, via the Internet and mobile phones. In the picture of Mexico City found below we can see that the main line from left to right is Reforma avenue the place where the \#yosoy132 protestors met for the massive rally towards the city center. The center, the Zocalo, is the brightest of all of the areas, which suggest a heavy connectivity. In this case, the importance of this main square to Mexico City's public life is also reflected in the Internet, in the virtual realm.

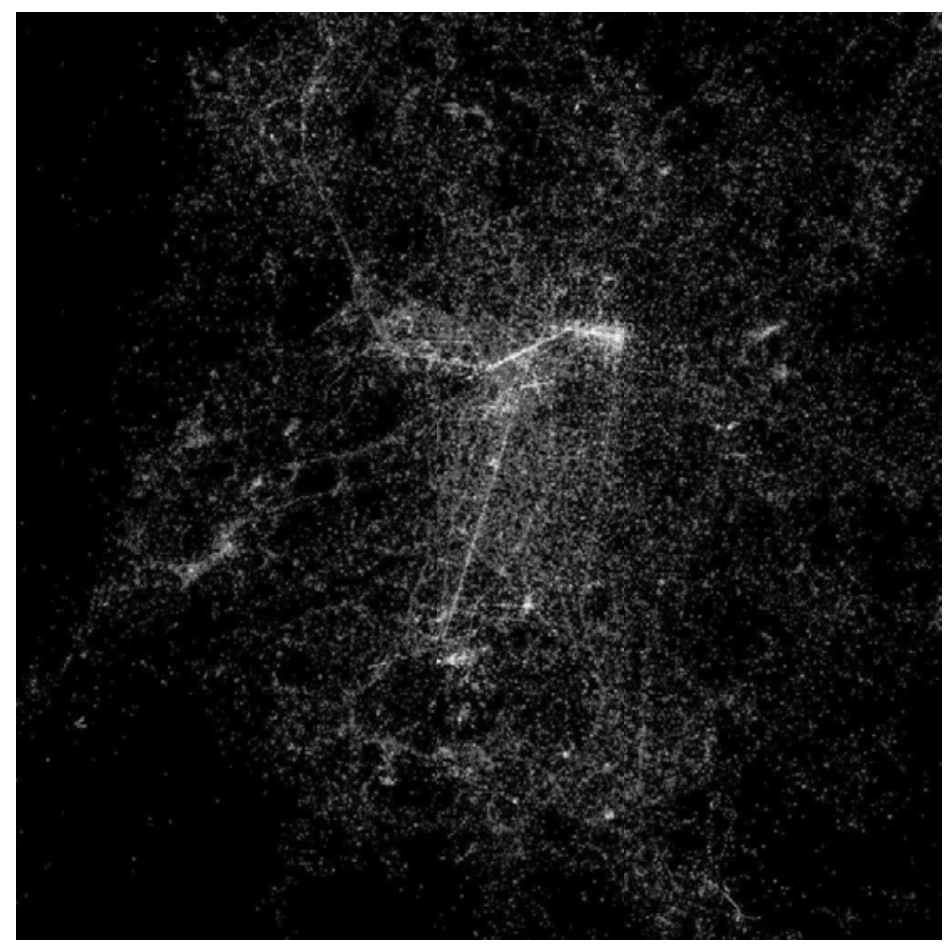

Figure 3: Map of Mexico City's twitter usage shows main public spaces as hubs of interaction (Eric Fisher, Flickr)

It comes as no surprise, then, that the \#yosoy132 movement jumped from the secluded area of Santa Fe to central spaces of the city, like Reforma or the Zocalo. Gallo, citing Koolhaas, says that generic cities, like Santa Fe, are uniform and lacking history. They are massproduced, like a ready-made consumption object, and have no liveliness because they lack a heterogenous public space. Instead, they are conceived as empty space, as space of transit. On the other hand city centers, like Reforma and el Zocalo are places saturated with history and 
symbolism, they are covered in emotional layers and fully integrated into the cultural coordinates of city life. Having a mass protest there becomes a symbolic act as many of the government buildings are situated nearby.

The jump of the \#yosoy132 movement across spaces challenges our conception of the city as a firmly bounded or easily contained territory. In order to avoid conceiving the city as this steady unit we can look at the mechanisms for integration and roles of cooperation of local actors, interaction and diversity. The focus on the relational aspect is important because technology induces a crisis of boundary, reference and dimension, making it increasingly hard to distinguish between exterior and interior, between here and elsewhere (Auge; Mcquire).

This explains why, from the beginning, the pressure to define the movement was monumental--it was hard to determine its scope and boundaries. Thus, to give its local actions symbolic and geographic frames of reference, the first massive march appeared as images like the ones from other mass protests that took place in Egypt or Occupy Wall Street. These images of social media protests were so important during 2011 that Time Magazine gave it the Person of the Year award to The Protestor. Images of Occupy Wall Street, the Arab Spring and the Spanish Indignados circulated through newspapers, TV and the Internet constantly. This is a case of what Auge calls the overabundance of Historic events-a symptom of the acceleration of history brought about by globalization. It is also a symptom of the acceleration of space, where screens on the planet gives us an assemblage of the world as relatively homogenous in its diversity. (Auge, 1995)

Thus, coming up with the movement's story became a foundational act, one that established momentary boundaries and roles within the city because it delimited the players and the space where they congregated. According to De Certeau spatial stories are needed to claim space when moving through a city. In this case, the story of the protest in Mexico City mixed with that of the global protestor, claiming, albeit momentarily, the position of the movement vis-àvis History. Thus, the images of the protestor turned mythic in the Barthean sense, in that they came to represent History developing before one’s eyes.

In the same way, words like the "Mexican Spring” were constantly used to define \#yosoy132; these words served as a performative act and anesthetized the phenomenon, poaching global 
stories for local purposes. In other words, images of mass unrest became dislodged from their local frames of reference and re-appropriated by \#yosoy132 in order to make sense of the Mexican protest as a global condition.

In all of these images, the masses meet in a symbolic public space to express anger and contempt against the established order. Most of the times the spaces where they meet were symbolic of the nation-state. With the global circulation of images through social media, though, these public spaces became integrated into transnational discourses of protest. Ironically, though, it was this movement towards framing the protest as a global story that reduced its power. As the images of these encounters circulate globally, the space and the multitude becomes entangled within the politics of these global circuits. The space is thus dislodged from national frames of reference and inserted into symbolisms that exceed the nation state in order to become representative of a global situation. But the goal, to destabilize Enrique Pena Nieto, becomes lost amongst the global hype.

Activists in Mexico City have followed the footsteps of protestors in Cairo, New York and Madrid in organizing displays of public unrest that are highly dependant on social media. Mexico City's unrest, however, did not take place on a global vacuum: there were relations that happened between people from different parts of the cities, different neighborhoods, and which were highly important in the emotional structuring of the movement. The student movement was caused through a Twitter contagion, but it also relied in imaginaries of global unrest to keep organizing itself as a closed crowd.

Mexico City would be seen as a case study to ask questions that could of space and networks that could be applied to similarly globalized megalopolises--like Sao Paolo, Johannesburg, Mumbai, Lagos. As a platform, Mexico City, allowed for the multiple actors of this movement to participate actively, even when the events developed in different spaces. In this sense, the Internet reconfigured the relation that many urbanites had with the space of the city: public space became a hybrid real in which global and local networks together coincided. Face-to-face encounters allowed for a collective identity to be enacted in a series of important events that happened in Mexico City. Then, the movement disintegrated, leaving behind an ephemeral moment that succumbed to the pressure of a fragmented megalopolis 


\section{References}

Auge, "Non-places: An introduction to an anthropology of hypermodernity” 1995

Barthes, “Mythologies” Farrar, Straus and Giroux (1972)

Canclini,Nestor Garcia “ Mexico City, 2010: Improvising Globalization” in Other Cities, Other Worlds, edited by Andreas Huyssen, Durham, Duke University Press, 2008

Castells, Manuel. "Networks of Outrage and Hope: Social Movements in the Internet Age” Polity, USA, 2012

De Certeau; “The Practice of Everyday Life”: Polity, 2012

Gallo, Ruben. The Mexico City Reader, electronic version

Mazzarella, William "Who is afraid of the Crowd"

Mcquire, Scott “The Media City “London, Sage, 2008

Monsivais, Carlos. Los rituales del caos, Mexico, Ediciones Era, 1995

Robinson, Jennifer “Urban geography: world cities, or a world of cities,” Progress in Human Geography 29, 6 (2005): 757-765. 